\title{
Economic Impact of Lockdown on Livestock and Poultry Production in Punjab and Remedial Measures
}

\author{
Palwinder Singh $^{1 *}$, A. P. S. Dhaliwal ${ }^{1}$, Vinay Singh $^{2}$ and G. S. Dhillon ${ }^{2}$ \\ ${ }^{1}$ Punjab Agricultural University, Ludhiana, India \\ ${ }^{2}$ Krishi Vigyan Kendra, Bathinda, India \\ *Corresponding author
}

A B S T R A C T

K e y w o r d s
Covid-19,
Lockdown, Impact,
Entrepreneurs,
Remedies, Dairy,
Poultry, Piggery
Article Info
Accepted:
$\begin{aligned} & \text { 04 November } 2020 \\ & \text { Available Online: } \\ & 10 \text { December } 2020\end{aligned}$

\section{Introduction}

The outbreak of Covid-19 is being seen all over the world. The epidemic began in Chinese city Wuhan, but in a short time it has affected the entire world. Its arrival in India took place in the month of January and first case India was recognized on 30th January 2020 , in Kerala and gradually it spread in whole of the country (Unnithan, 2020). In February 2020, the World Health Organization designated the disease COVID19 and declared it as Pandemic on 11th March. The virus that causes COVID-19 is designated severe acute respiratory syndrome corona virus 2 (SARS-CoV-2) (Li et al 2020). This epidemic in Punjab was reported on March 19th, 2020 in Nawashahar. Subsequently, the Punjab Government imposed lockdown from March 21, 2020 which resulted in a direct effect on economic conditions of state. Agriculture and its allied occupations are the most important and valuable sector of India. It is worth to specify that it engages $53 \%$ of the total work force of India. Right now, it contributes around 17\% of Indian GDP at current prices (Ministry of Finance, 2020). 
During the lockdown farmers engaged in livestock and poultry sector faced a lot of difficulties. Due to these problems net income of farmers decreased. Input cost increased during lockdown due to rise in price of feed especially concentrate. News reports showed that the closing of sweetshops, hotels, restaurants, and tea shops during the lockdown decreased the sales of dairy, while poultry farmers were seriously influenced by rumors, particularly via online media that chicken is the transmitter of COVID-19 (Mahendra Dev, 2020). Due to the lockdown, almost all the meat and poultry shops were shut in many places. Farmers have resorted to many ways to overcome the situation. In some parts, chicks were culled and in others, chicken was sold at a very low price. Present study was designed for the evaluation of the hurdles faced by entrepreneurs in livestock and poultry sector and mitigation strategy formulated by Krishi Vigyan Kendra, Bathinda for the entrepreneurs. Findings of the study will serve as a feedback for administrators, agriculture extension scientists and skill development trainers of Krishi Vigyan Kendra's. The analytical study of problems faced by livestock and poultry farmers during lockdown will be helpful for planning and organization of future training programs.

\section{Materials and Methods}

The present study was conducted to understand the economic impact lockdown imposed due to corona virus (COVID-19) on animal husbandry in Punjab. Three major subsidiary occupations were selected in this study namely dairy, poultry and piggery. The survey was conducted with the help of previously developed questionnaire and interview schedule basis. Sixty farmers were selected from each of the occupation. The questionnaire was provided with the list of problems faced by farmers to tick on, thereby indicating the economic impact of lockdown. Convenient sampling methods were used for data collection and were represented as frequencies and percentages. A sum of 180 individuals has responded to the questionnaire designed towards the impact of lockdown due to the pandemic covid-19 on animal husbandry. Collected data utilized for statistical analysis and results presentation in tabled/graphic form.

\section{Results and Discussion}

\section{Dairy}

From the study it was observed that majority of the dairy farmers faced the problem of reduced milk price (Table 1). Requirement of milk in market decreased due to closer of local dairies, cantonment areas, sweet shops, hotels, restaurants as well as marriages which has resulted in average loss of Rs. 5 per litre (Table 4). The highest mean score $(97.5 \%)$ was recorded for this parameter, while lack of transportation means showed mean score of 95 percent. Supply of quality feed reduced which was predominantly due to lack of access to markets and lack of transportation means.

Reduced price of milk and lack of transportation means were identified as major problems and ranked at first and second position, respectively. Lack of veterinary aids obtained mean score of 92.5 percent and ranked third. Non-availability of migration passes and reduced supply of quality feed exhibited mean score of 71.5 percent and achieved rank fourth.

Problem and purchase of animals also perceived as important problem in dairy farming and it gained mean score of 82.5 percent. Access to markets ranked sixth and obtained mean score of 80 percent. The similar findings are reported by Braja et al., 
2020. Shashidhar (2020) also reported negative impacts of incidence of COVID-19 on the dairy industry in India which significantly reduced the overall demand. Present studies also revealed a decrease in average selling price of milk from Rs. 43 to Rs. 38 during the lockdown due the above discussed problems.

\section{Poultry}

The data presented in Table 2 reveals that all the respondents have placed reduced price of egg or meat as a major problem faced during the lockdown. Reduction in sale of eggs or meat has also been cited by most respondents $(97.5 \%)$. This is caused by reduced demand due to rumours. Even before the country registered the first case of COVID-19, the rumours of poultry birds as the likely carrier of the virus widely circulated in social media had led to reduced demand of the chicken meat in several parts of the country.

This problem is followed by reduced availability of improved breeds (90\%), lack of transportation $(82.5 \%)$, unavailability of quality poultry equipments $(80 \%)$, delayed feed supply $(77.5 \%)$, low production $(70 \%)$ and poor quality of feed (62.5\%), respectively. Poultry farmers incurred massive losses since February 2020, because of rumours associated with the poultry products led to a collapse in demand for poultry products. Due to decreased demand, price of chicken and egg reduced to the tune of 67.6 percent and 44.4 percent, respectively (Figure 1).

\section{Pig farming}

It was found that the lack of sale was the major problem faced by pig farmers with a mean score of 95 percent and was ranked first (Table 3). Reduced price of pork with a mean score of 93 percent was the second most important problem followed by non availability of waste for feeding pig $(88.3 \%)$ and lack of veterinary aid (78.3\%).

Moreover, 63.3 percent farmers were forced for fattening of existed stock which was mainly caused by lack of sale during the lockdown. Figure 1 clearly indicates a reduced average selling price of pork to the tune of 28.1 percent due to adverse effects of the lockdown. The present findings are in line with Hart et al (2020).

Table.1 Distribution of Dairy farmers according to the problems faced during lockdown

\begin{tabular}{|l|c|c|c|}
\hline Problem & $\begin{array}{c}\text { Frequency } \\
\text { (N=60) }\end{array}$ & Percentage & Ranking \\
\hline Lack of transportation means & 57 & 95.0 & II \\
\hline Access to markets & 48 & 80.0 & VI \\
\hline Reduced supply of quality feed & 53 & 87.5 & VI \\
\hline Increased feed cost & 47 & 77.5 & VII \\
\hline Lack of veterinary aids & 56 & 92.5 & III \\
\hline Non availability of migration passes & 53 & 87.5 & VI \\
\hline Reduced supply of quality semen & 45 & 75.0 & VIII \\
\hline Reduced price of milk & 59 & 97.5 & I \\
\hline Reduced availability of feed & 41 & 67.5 & IX \\
\hline Problem in sale and Purchase of animals & 50 & 82.5 & V \\
\hline
\end{tabular}


Table.2 Distribution of poultry farming according to the problems faced during lockdown

\begin{tabular}{|l|c|c|c|}
\hline Problem faced & Frequency (N=60) & Percentage & Ranking \\
\hline $\begin{array}{l}\text { Unavailability of quality poultry } \\
\text { equipments }\end{array}$ & 48 & 80.0 & V \\
\hline Reduced availability of improved breeds & 54 & 90.0 & III \\
\hline Reduced price of egg or meat & 60 & 100.0 & I \\
\hline Poor quality of feed & 38 & 62.5 & VIII \\
\hline Lack of transportation & 50 & 82.5 & IV \\
\hline Low production & 42 & 70.0 & VII \\
\hline Delayed feed supply & 47 & 77.5 & VI \\
\hline Reduction in sale of eggs or meat & 59 & 97.5 & II \\
\hline
\end{tabular}

Table.3 Distribution of pig farmers according to the problems faced during lockdown

\begin{tabular}{|l|c|c|c|}
\hline & Frequency $\mathbf{( N = 6 0 )}$ & Percentage & Ranking \\
\hline Lack of sale & 57 & 95 & I \\
\hline Lack of veterinary aid & 47 & 78.3 & IV \\
\hline Price of pork reduced & 56 & 93.3 & II \\
\hline Non availability of waste & 53 & 88.3 & III \\
\hline $\begin{array}{l}\text { Forced for fattening of existed } \\
\text { stock }\end{array}$ & 38 & 63.3 & V \\
\hline
\end{tabular}

Table.4 Economic impact of lockdown

\begin{tabular}{|c|c|c|c|}
\hline \multirow[t]{2}{*}{ Product } & \multicolumn{2}{|c|}{ Average selling price (Rs.) } & \multirow{2}{*}{$\begin{array}{c}\text { Price reduced } \\
\text { (Rs.) }\end{array}$} \\
\hline & Before lockdown & During lockdown & \\
\hline 1 Litter milk & 43 & 38 & 5 \\
\hline 1 egg & 4.5 & 2.5 & 2 \\
\hline $1 \mathrm{Kg}$ chicken & 34 & 11 & 23 \\
\hline 1 kg pork & 160 & 115 & 45 \\
\hline 1 Broiler & 200 & 110 & 90 \\
\hline
\end{tabular}

Fig.1 Percentage reduction in average prices of major products

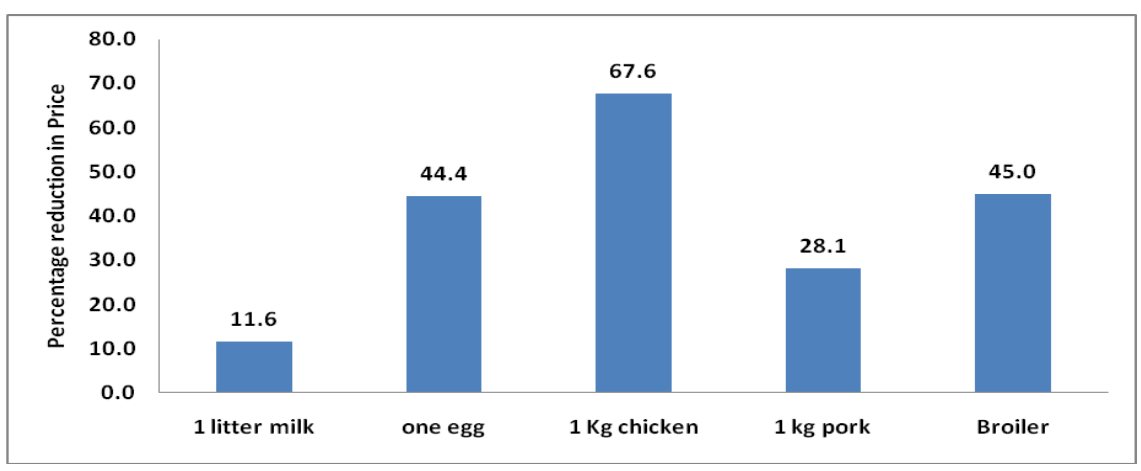




\section{Remedial measures during the lockdown}

After reviewing the problems of agriculture allied occupations, Krishi Vigyan Kendra, Bathinda has formulated some remedial measures for better and smooth livestock and poultry production to avoid economic downturn. All the farmers were further advised to download and register in Arogya Setu application in their mobiles. They were also advised to strictly follow the government directives on social distancing in all activities. The curfew passes were made available to dairy and poultry farmers for smooth marketing of milk, milk products, egg and meat. The poultry farmers were also advised to go for moulting technique which can be achieved by keeping the egg laying birds without feed for 7-8 days, then started feeding from $10 \mathrm{gram} / \mathrm{bird} /$ day and increased daily by 10 grams to normal in 22 days. Hence, egg lying was restored to normal in 28 days and even cost of feed was saved. Farmers were also advised to wash hands with soap/sanitizer and wear masks. Additional produce was utilized by making value added products. Dairy farmers were suggested to make other valuable products from milk like ghee which can be easily stored and sold after lockdown. For the sale of milk and eggs, the farmers were advised to do digital payment as far as possible. For pig farmers non availability of waste was a major problem and due to lack transportation means purchasing of pig feed was also not possible during the lockdown. So, they were advised to use locally available feed ingredients based on availability in that particular area.

It is concluded from the study that lockdown caused a negative impact on the economic status of the entrepreneurs in livestock by reducing their income. Dairy farmers were not much affected as they had a regular income through sale of milk, but the livelihood of poultry and pig farmers was severely affected during the covid-19 lockdown. Market sale of produce directly affected during this period. This period also shows us new path in the direction of processing and value addition so that the products can be increased and utilized in the lean period of time.

\section{References}

Braja Bandhu Swain, Kennady Vijayalakshmy, Habibar Rahman. Impact of COVID-19 on livestock sector in India: An economic analysis. J Entomol Zool Stud 2020; 8(4): 1701-1703.

Hart Chad, Hayes Dermot J, Jacobs, Keri L, Schulz Lee L and Crespi John "The Impact of COVID-19 on Iowa's Corn, Soybean, Ethanol, Pork, and Beef Sectors" (2020). CARD Policy Briefs. 30.

Li Q, Guan X, Wu P, Wang X, Zhou L, Tong Y. Early Transmission Dynamics in Wuhan, China, of Novel Corona virus-Infected Pneumonia. N. Engl. J Med. 2020; 382(13):1199-1207.

Mahendra Dev, S. (2020), "Addressing COVID19 impacts on agriculture, food security, and livelihoods in India", available at: www.ifpri.org/blog/addressing-COVID19-impacts-agriculture-foodsecurity-andlivelihoods-india

Ministry of Finance. (2020). Economic Survey of India 2019-20. New Delhi. https://doi.org/10.4324/9781315016702.

Shashidhar A (2020) Coronavirus Impact: Dairy Industry Faces 30\% Dip in Demand. Business Today. Available from: https://www.businesstoday.in/current/corp orate/coronavirus-impact-dairy-industryfaces-30--dip-in-demand/story/400517. html. Retrieved on 18-04-2020.

Unnithan, G. (2020). Kerala reports first confirmed corona virus case in India India News, India Today. Retrieved from https://www.indiatoday.in/india/story/kera la-reportsfirst-confirmed-novelcoronavirus-case-in-india1641593-202001-30.

\section{How to cite this article:}

Palwinder Singh, A. P. S. Dhaliwal, Vinay Singh and Dhillon, G. S. 2020. Economic Impact of Lockdown on Livestock and Poultry Production in Punjab and Remedial Measures. Int.J.Curr.Microbiol.App.Sci. 9(12): 230-234. doi: https://doi.org/10.20546/ijcmas.2020.912.030 